\title{
The Involvement of Granulosa Cells in the Regulation by Gonadotropins of Cyp17a1 in Theca Cells
}

\author{
HANAKO KAKUTA, TAISEN IGUCHI and TOMOMI SATO
}

Graduate School of Nanobioscience, Yokohama City University, Yokohama, Japan

\begin{abstract}
Background/Aim: Theca cells produce androgen by 17a-hydroxylase-17,20-lyase encoded by Cyp17al, and conversion of androgen to estrogen in granulosa cells is regulated by gonadotropins. Women with polycystic ovarian syndrome (PCOS) exhibit elevated levels of androgens due to high Cyp17al expression and alterations in gene expression in granulosa cells. The aim of this study was to examine the interaction between theca and granulosa cells in PCOSmodel mice. Materials and Methods: To produce PCOSmodel mice, neonatal mice were injected with 1 g $\mathrm{gP}$ for 3 days from the day of birth. Gonadotropins were injected according to the superovulation protocol to 3-month-old control mice and PCOS-model mice. Histological changes and expression of genes involved in steroidogenesis, ovulation and luteinization were investigated by immunohistochemistry and real-time RT-PCR, respectively. Results: Pregnant mare serum gonadotropin (PMSG) induced the expression of genes involved in steroidogenesis in control prepubertal mice, whereas human chorionic gonadotropin (hCG) reduced Cyp17al expression and induced phospho-ERK1/2 in granulosa cells. Cyp17al was reduced in PMSG-primed $P C O S$-model mice regardless of hCG injection, and PMSG induced phosphorylation of ERK1/2 in granulosa cells. Conclusion: Phospho-ERK1/2 in granulosa cells can be correlated with reduced Cyp17al expression in theca cells, and the interaction between granulosa and theca cells may be impaired in PCOS-model mice.
\end{abstract}

In the mouse ovary, 17 $\alpha$-hydroxylase-17,20-lyase (CYP17A1), localized in theca cells of large antral and preovulatory follicles,

This article is freely accessible online.

Correspondence to: Dr. Tomomi Sato, Graduate School of Nanobioscience, Yokohama City University, 22-2 Seto, Kanazawaku, Yokohama 236-0027, Japan. Tel: +81 457872394, Fax: +81 457872413, e-mail: tomomi@yokohama-cu.ac.jp

Key Words: Theca cell, Cyp17a1, luteinizing hormone, granulosa cell, PCOS, androgen synthesis. converts progesterone to $17 \alpha$-hydroxypregnenolone and then androstenedione by $17 \alpha$-hydroxylase and $\mathrm{C}_{17-20}$ lyase activities, respectively $(1,2)$. The expression of Cyp $17 a 1$ mRNA in the ovary is induced by luteinizing hormone $(\mathrm{LH})$ from the pituitary via $\mathrm{LH}$ receptor, encoded by Lhcgr, and LH enhances cAMP production (3). Although LH is the main factor inducing expression of Cyp17a1, in vitro studies have also revealed that factors from granulosa cells and oocytes, such as inhibin, activin and growth differentiation factor 9 (GDF-9), regulate the expression of Cyp17al $(4,5)$. Additionally, female mice lacking extracellular signal-regulated kinases 1 and 2 (ERK1/2) in granulosa cells generated from $\mathrm{Erk1}^{-/-}$and $E r k 2^{g c-/-}$ mice contain preovulatory follicles with elevated levels of serum $17 \beta$ estradiol (E2), but no corpora lutea (CLs) (6). When Erk1/2gc${ }^{\prime}$ - mice are treated with gonadotropins, events associated with ovulation do not occur, and the levels of E2 and the expression of Cyp17al and Cyp19al remain high compared with those in the wild-type mice. These facts indicate the involvement of granulosa cells in the regulation of Cyp 17al in theca cells.

Polycystic ovarian syndrome (PCOS) is one of the most common endocrine disorders in reproductive-aged women (7). In its typical form, there is association of hyperandrogenism with chronic anovulation (8). It is known that Cyp17al expression in theca cells from PCOS women is up-regulated by hypersecretion of LH (9-11). In addition to impaired steroidogenesis and gene expression in theca cells of PCOS women, gene expression in granulosa cells, especially transcription factors related to $\mathrm{Wnt} / \beta$-catenin and mitogen-activated protein kinase (MAPK)/ERK pathways, and proteins in follicular fluid are also altered compared to healthy women (12-14). These facts suggest that not only the alterations in theca cells but also those in granulosa cells are responsible for PCOS pathology.

In order to study the pathogenesis of PCOS, animal models including rodents are used. Rodent models of PCOS are induced by perinatal androgenization (15). A single treatment of rats with testosterone propionate (TP) $(1-1,000 \mu \mathrm{g})$ within the first 5 days of life causes anovulation or reduced ovulation (16-19). Rats exposed to $100 \mu \mathrm{g}$ TP on Day 1 or 5 show acyclicity and polycystic ovaries with atretic follicles which are cystic follicles with thin granulosa cell layers $(19,20)$. 
Mice treated with TP for 3 days starting from the day of birth also exhibit anovulation and the presence of polyfollicular ovaries $(21,22)$. A nonaromatizable androgen, $5 \alpha$ dihydrotestosterone (DHT), is also used to induce PCOS in animal models. Prenatal DHT exposure of rats and mice causes irregular estrous cycle and reduced ovulation (23). These treatments have shown many characteristics of PCOS including hyperandrogenism, elevated LH, disrupted cyclicity, presence of follicular cysts and altered insulin sensitivity in rodents. Therefore, the study of the interaction between granulosa and theca cells using a mouse model of PCOS is helpful to understand PCOS pathology in women.

This study aimed at studying the involvement of granulosa cells in the regulation of Cyp17al in theca cells in response to gonadotropin treatments in control and PCOS-model mice. The expression of genes involved in steroidogenesis regulated by gonadotropins, and localization of CYP17A1 and phospho-ERK1/2 were investigated in immature mice.

\section{Materials and Methods}

Animals and treatments. C57BL/6J mice (CLEA Japan, Tokyo, Japan) were housed under a 12-h light/12-h dark cycle (lights off at 20:00 h) with controlled temperature $\left(25^{\circ} \mathrm{C}\right)$ and given a commercial diet (MF, Oriental Yeast Co., Tokyo, Japan) and fresh tap water ad libitum. All animals were maintained in accordance with the NIH Guide for the Care and Use of Laboratory Animals. Experiments were approved by the Institutional Animal Care Committee of the Yokohama City University. To produce PCOS-model mice, female pups were given daily subcutaneous injections of $1 \mu \mathrm{g}$ testosterone propionate (TP) (Sigma-Aldrich, St. Louis, MO, USA) dissolved in $0.02 \mathrm{ml}$ sesame oil or the vehicle alone for 3 days starting on the day of birth.

Twenty-one-day-old and 3-month-old female mice at the day of diestrus and PCOS-model female mice were given 5 IU of pregnant mare serum gonadotropin (PMSG, ASKA Pharmaceutical Co., Ltd., Tokyo, Japan) intraperitoneally in the morning (10:00 h) followed by 5 IU of human chorionic gonadotropin (hCG, ASKA Pharmaceutical Co., Ltd.) $48 \mathrm{~h}$ later. Ovaries from mice at 48 and $56 \mathrm{~h}$ after PMSG and 4, 8, 12, 24 and $48 \mathrm{~h}$ after hCG were collected, fixed for histological analysis or frozen for quantitative real-time RT-PCR analysis ( $\mathrm{n}=5-8$ in each group).

Stages of the estrus cycle of 3-month-old control mice were determined by cytologic evaluation of vaginal smears. Ovaries from mice at diestrus or estrus were fixed for histological analysis or frozen for quantitative real-time RT-PCR analysis $(n=5)$.

Histological analysis. Right ovaries were fixed in Bouin's fixative overnight, dehydrated through a graded series of ethanol, embedded in paraffin and serially sectioned at $8 \mu \mathrm{m}$. Sections were deparaffinized and stained with hematoxylin and eosin (HE). The numbers of small antral $(140-250 \mu \mathrm{m})$, large antral $(250-390 \mu \mathrm{m})$ and preovulatory $(>390 \mu \mathrm{m})$ follicles, and corpora lutea (CLs) in the ovary were counted.

Immunohistochemistry. Ovaries were fixed in 4\% paraformaldehyde overnight at $4^{\circ} \mathrm{C}$, dehydrated through a graded series of ethanol, embedded in paraffin and serially sectioned at $6 \mu \mathrm{m}$. Sections were deparaffinized and rehydrated. For antigen retrieval, sections were microwaved for $8 \mathrm{~min}$ in $10 \mathrm{mM}$ citric acid buffer ( $\mathrm{pH} \mathrm{6.0)}$ and left for $30 \mathrm{~min}$ at room temperature (RT) (CYP17A1) or microwaved until boiling and kept for 12 min at a sub-boiling temperature in 10 $\mathrm{mM}$ citric acid buffer ( $\mathrm{pH}$ 6.0) and left for $30 \mathrm{~min}$ in RT (ERK1/2 and phospho-ERK1/2). Sections were then immersed in $3 \% \mathrm{H}_{2} \mathrm{O}_{2}$ for $10 \mathrm{~min}$ to eliminate endogenous peroxidase. After washing in PBS (CYP17A1) or TBS (ERK1/2 and phospho-ERK1/2), sections were incubated with 5\% normal goat serum (Vector Laboratories, Burlingame, CA, USA) for $45 \mathrm{~min}$, and then anti-human CYP17A1 rabbit polyclonal antibody (Proteintech, Rosemont, IL, USA) at 1:1000 dilution, anti-human ERK1/2 (ERK1/2) rabbit monoclonal antibody (Cell Signaling Technology, Danvers, MA, USA) at 1:100 dilution, anti-human phospho-ERK1/2 (phospho-ERK1/2, pERK1/2) rabbit monoclonal antibody (Cell Signaling Technology) at 1:100 dilution, or negative control rabbit immunoglobulin fraction (Dako Cytomation, Glostrup, Denmark) in PBS or TBS at $4^{\circ} \mathrm{C}$ overnight. After incubation with a secondary antibody, CYP17A1, ERK1/2, and p-ERK1/2 were detected by a standard Elite ABC kit (Vector Laboratories) and diaminobenzidine (Sigma-Aldrich). Hematoxylin was used for counterstaining.

RNA isolation and quantitative real-time RT-PCR. Ovaries were homogenized in TRIzol (Thermo Fisher Scientific, Waltham, MA, USA). Total RNA isolated from ovaries was purified by DNase I (Roche, Penzberg, Germany) and with a RNeasy total RNA kit (Qiagen, Chatsworth, CA, USA) to remove genomic DNA, and reverse transcribed into cDNA by SuperScript II reverse transcriptase (Thermo Fisher Scientific) using oligo dT primer (Thermo Fisher Scientific). Real-time PCR was carried out using Applied Biosystems StepOnePlus ${ }^{\text {TM }}$ Real Time PCR System (Thermo Fisher Scientific) with Fast SYBR Green Master Mix (Thermo Fisher Scientific). Relative mRNA expression of Cyp11a1, Cyp17a1, Cyp19a1, Hsd3b1, Hsd17b1, Lhcgr, follicle stimulating hormone receptor $(F s h r)$, epidermal growth factor receptor $(E g f r)$, amphiregulin (Areg), ephiregulin (Ereg), betacellulin (Btc), secreted frizzled-related protein 4 (Sfrp4), Prostaglandin-endoperoxide synthase 2 (Ptgs2) and tumor necrosis factor-alpha-induced protein 6 (Tnfaip6) was determined by the standard curve method. Peptidylpropyl isomerase A (Ppia) was chosen as an internal standard to control for variability in amplification due to differences in starting mRNA concentrations. Sequences of oligonucleotides used as primers for real-time quantitative RT-PCR are shown in Table I.

Statistical analysis. Data are expressed as the mean \pm standard error. For multiple comparisons, treatment groups were compared using analysis of variance (ANOVA) followed by Tukey's post-hoc test. A statistically significant difference was defined at $p<0.05$.

\section{Results}

Effects of PMSG and hCG injections on the ovary of prepubertal mice. Prepubertal ovaries of 21 days of age mice contained a series of developing follicles but no preovulatory follicle and CL (Figure 1A, B and C). PMSG treatment for 48 $\mathrm{h}$ significantly increased the total number of antral follicles (Figure 1A and D). Preovulatory follicles were found in PMSG-primed mice following treatment with PMSG or hCG 
Table I. Sequences of oligonucleotides used as primers for real-time quantitative RT-PCR.

\begin{tabular}{|c|c|c|c|}
\hline Gene & Forward sequence (5' to 3') & Reverse sequence (5' to 3') & PCR product (bp) \\
\hline Cyp11al & GTGAATGACCTGGTGCTTCGT & TCGACCCATGGCAAAGCTA & 78 \\
\hline Cyp17a1 & GATCGGTTTATGCCTGAGCG & TCCGAAGGGCAAATAACTGG & 81 \\
\hline Cyp19 & TGATCATGGGCCTCCTTCTC & CCCAGACAGTAGCCAGGACCT & 76 \\
\hline$H s d 3 b 1$ & CAAGTGTGCCAGCCTTCATCT & GGCCATCAGGACGATCTTAT & 80 \\
\hline$H s d 17 b 1$ & CTGCGTGGTTATGAGCAAGC & CGCATTGCAGTCAAGAAGAGC & 77 \\
\hline Lhcgr & GAAATGGATTTGAAGAAGTACAAAG & CCATTGTGCATCTTCTCCAG & 99 \\
\hline Fshr & CTCTCAGAATGATGTCTTGGAGGTAAT & GATGTACAGCAGATTGTTAGCCTTTTC & 103 \\
\hline Areg & TCCGGCTATATTATAGATGATTCAGTCA & тCTCCTTCTGTCTTGTTTTTCTTGG & 74 \\
\hline Ereg & GCTCCCTGCCTCTTGGGT & TGCCTGTAGAAGGTGGGAACC & 58 \\
\hline Btc & CCAATGGCTCTCTTTGTGGAG & TGGGTTTTCACTTTCTGTCTAGGG & 73 \\
\hline Egfr & AGCAGTTGCCCCAAATGTGAT & ACGACAGCGATGGGAACATT & 120 \\
\hline $\operatorname{Ptgs} 2$ & GCTGTACAAGCAGTGGCAAA & TTCTGCAGCCATTTCCTTCT & 144 \\
\hline Sfrp4 & CGGTCTATGACCGTGGAGTT & GGACCTTTCTTGCACCATCA & 110 \\
\hline Tnfaip6 & GGTGGTCGTCTCGCAACCTA & CAAGCAGCACAGACATGGAA & 71 \\
\hline Ppia & AGGTCCTGGCATCTTGTCCAT & CCATCCAGCCATTCAGTCTTG & 93 \\
\hline
\end{tabular}

for $48 \mathrm{~h}$ and $12 \mathrm{~h}$, respectively in (Figure 1D and E). CLs were found in all ovaries of PMSG-primed mice following treatment with hCG for 24 and $48 \mathrm{~h}$ (Figure $1 \mathrm{~A}$ and F).

The percentage of small antral follicles was significantly decreased at $48 \mathrm{~h}$ after PMSG treatment but it was significantly increased at $4 \mathrm{~h}$ after hCG treatment (Figure 1B). The percentages of large antral follicles and preovulatory follicles were significantly increased at $48 \mathrm{~h}$ after PMSG treatment. The percentage of preovulatory follicles was significantly decreased at $8 \mathrm{~h}$ after hCG compared with that at $48 \mathrm{~h}$ after PMSG treatment (Figure 1B).

Time course of gene expression involved in steroidogenesis after PMSG and hCG injections in 21-day-old mouse ovaries. The expression of Cypllal and Hsd3bl was not altered until $24 \mathrm{~h}$ after hCG treatment in PMSG-primed mice (Figure 2), however, it significantly increased at $48 \mathrm{~h}$ after hCG when CLs were fully formed (Figures 1A and 2). PMSG treatment significantly increased the expression of Cyp17al and Cyp19al 48 h later, whereas hCG suppressed expression of Cyp17al, Cyp19al and Hsd17bl at $4 \mathrm{~h}$. Suppression of Cyp17al, Hsd17b1 and Cyp19al was not induced without hCG injection at $56 \mathrm{~h}$ after PMSG treatment (Figure 2). Especially, Cyp 17 al expression was significantly reduced at $8 \mathrm{~h}$ after hCG injection compared with that at 56 $\mathrm{h}$ after PMSG injection.

The expression of gonadotropin receptors required for steroidogenesis and folliculogenesis, Lhcgr and Fshr, was induced by PMSG and reduced by hCG. The Lhcgr expression was significantly reduced at $8 \mathrm{~h}$ after hCG injection compared with that at $56 \mathrm{~h}$ after PMSG injection, and it was increased again at $48 \mathrm{~h}$ after hCG treatment (Figure 2).
The localization of CYP17A1 and phospho-ERK1/2 in 21-dayold mouse ovaries. To investigate the involvement of granulosa cells in CYP17A1 expression, the localization of CYP17A1, phospho-ERK1/2 and ERK1/2 in the ovary of 21day-old mice after the gonadotropin treatments was analyzed by immunohistochemistry. In the ovary of 21-day-old intact mice, ERK1/2 and phospho-ERK1/2 positive cells but not CYP17A1 positive cells were observed in the theca cell layer (Figure 3A, E, I, M, Q and U). PMSG injection induced strong expression of CYP17A1 in the theca cell layers of large antral and preovulatory follicles (Figure 3B and F), however, the localization of ERK1/2 positive cells was not affected and staining for phosho-ERK1/2 was observed in theca cells (Figure 3R, V, J and N). Five out of 8 mouse ovaries showed no or little CYP17A1 expression in the theca cell layer at $8 \mathrm{~h}$ after hCG injection (Figure 3C and $\mathrm{G}$ ). Interestingly, preovulatory follicles which showed no staining for CYP17A1 expression contained phosho-ERK1/2 positive-granulosa cells and theca cells (Figure $3 \mathrm{~K}$ and $\mathrm{O}$ ). On the other hand, preovulatory follicles which did not contain phosho-ERK1/2 positive granulosa cells still expressed CYP17A1 in theca cells at $8 \mathrm{~h}$ after hCG injection (Figure 3D, H, L and P). hCG injection did not affect the localization of ERK1/2 positive cells (Figure 3S, W, T and X).

In granulosa cells, the main factors inducing ERK1/2 phosphorylation after the LH surge or hCG treatment are EGF-like ligands such as AREG, EREG and BTC (6). In order to investigate the time course changes in the expression of Areg, Ereg and Btc by gonadotropins, real-time RT-PCR was carried out. After hCG treatment, mRNA expression of Areg and Ereg was increased at $2 \mathrm{~h}$ and that of Btc at $4 \mathrm{~h}$, while were decreased at $4 \mathrm{~h}$ and $8 \mathrm{~h}$ after hCG, respectively. 

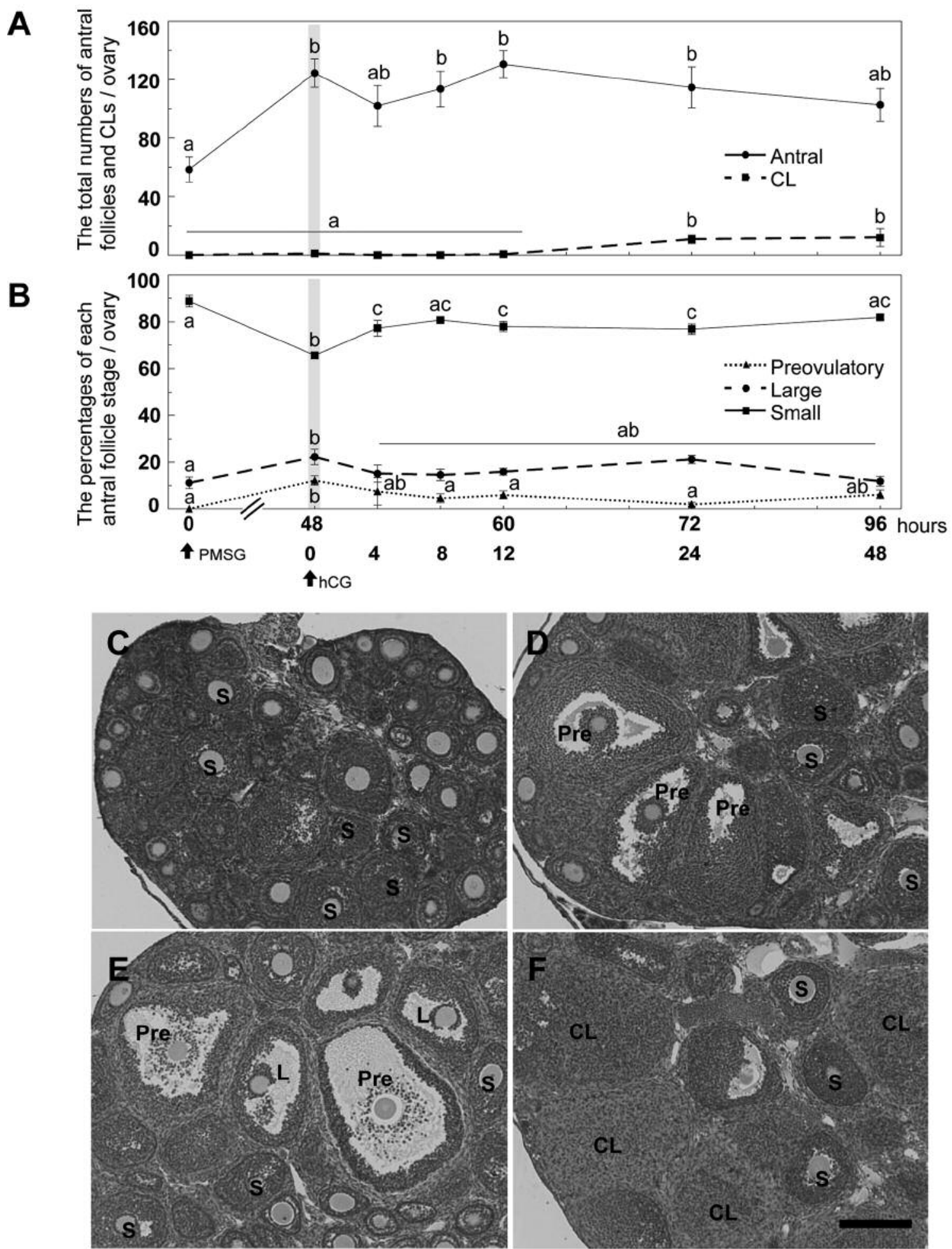

Figure 1. Effects of PMSG and hCG injections on the ovaries of prepubertal mice at 21 days of age. A: The total numbers of antral follicles and corpora lutea (CLs) in ovaries from prepubertal mice were counted at 0 and $48 \mathrm{~h}$ after PMSG injection and 4, 8, 12, 24 and $48 \mathrm{~h}$ after hCG injection, respectively. B: Follicle stage index, preovulatory $(>390 \mu \mathrm{m})$, large antral (250-390 $\mu \mathrm{m})$ and small antral follicles $(140-250 \mu \mathrm{m})$. C-F: HE staining of 21-day-old mouse ovaries at $0 h(C)$ and $48 h$ after PMSG $(D), 12 h(E)$ and $48 h(F)$ after $h C G$ in PMSG-primed mice. Bar=200 um. Different letters $(a, b$ and $c)$ on $A$ and $B$ indicate significant changes through the experiment $(p<0.05)$. S: Small antral follicle; L: large antral follicle; Pre: preovulatory follicle, $C L$ : corpus luteum. $n=5$ in each group. 


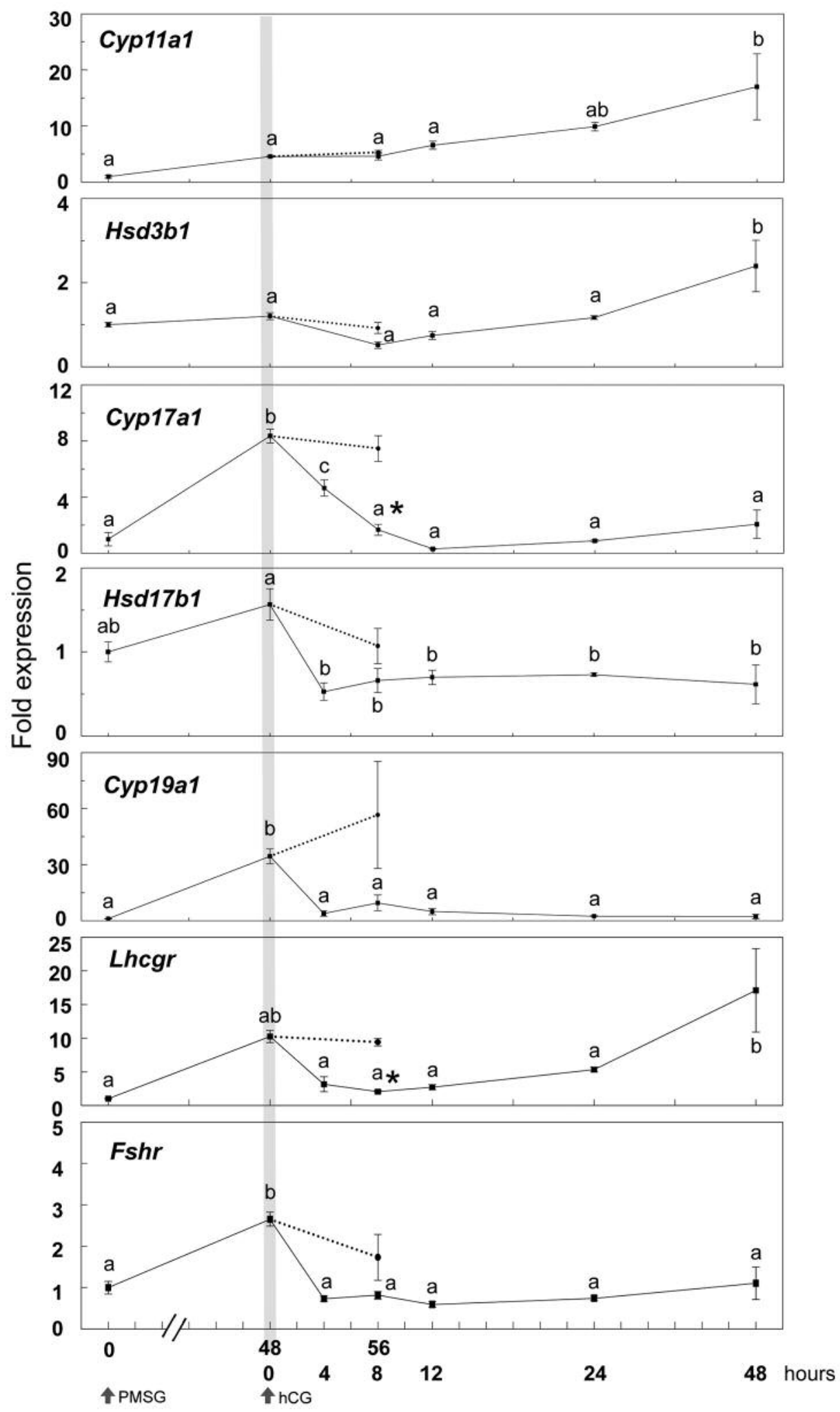

Figure 2. Time course changes in the expression of genes involved in ovarian steroidogenesis at 0,48 , and 56 h after PMSG injection and 4, 8, 12, 24, 48 $h$ after $h C G$ injection in 21-day-old mice. Data were expressed relative to mRNA expression in the ovaries before PMSG (=1.0). Different letters (a and $b)$ indicate significant changes in the expression of each gene $(p<0.05)$. ${ }^{*} p<0.05$, significant difference between PMSG-primed mice at $56 \mathrm{~h}$ with or without $h C G$. Straight line and dotted line indicate hCG treatment at $48 \mathrm{~h}$ after PMSG treatment and no hCG treatment, respectively. $n=5$ in each group. 


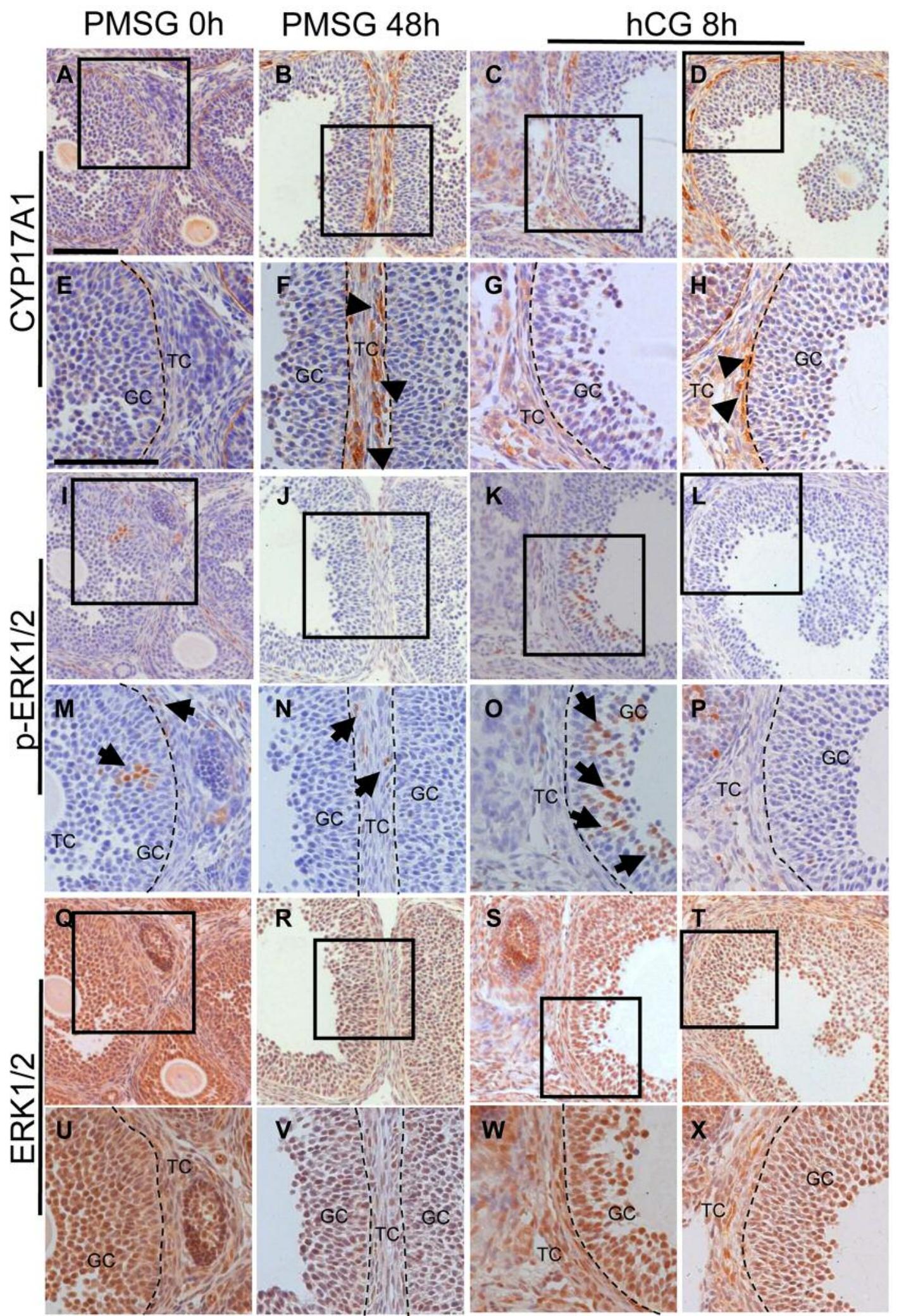

Figure 3. The localization of CYP17A1, phospho-ERK1/2 (p-ERK1/2) and ERK1/2 by immunohistochemistry in the ovary of 21-day-old non-treated mice $(A, E, I, M, Q$ and $U)$, mice treated with PMSG for $48 h(B, F, J, N, R$ and $V)$ and mice treated with $h C G$ for $8 h(C, D, G, H, K, L, O, P, S, T, I W$ and $X)$. Bar $=100 \mu \mathrm{m} . T C$, theca cells; GC, granulosa cells; arrowheads, CYP17A1 positive cells; arrows, $p$-ERK1/2 positive cells. $n=5-8$ in each group. 
In the absence of hCG, the expression of Areg, Ereg and Btc was not increased (Figure 4).

Histology and expression of genes involved in steroidogenesis in the ovary of 3-month-od PCOS-model mice compared with those of cycling control mice. High dose of TP $(5,10,25,50$ and $100 \mu \mathrm{g}$ ) induced severe hypertrophy and hyperplasia in the interstitial tissue similar to that in the ovary of neonatal diethylstilbestrol-treated mice (data not shown). Mice treated with $1 \mu \mathrm{g}$ TP for 3 days from the day of birth mimicked most of PCOS features, therefore, they were used as PCOS-model mice in the following experiments.

The expression of Cypllal was reduced in the ovary of 3-month-old PCOS-model mice compared with that of agematched cycling mice, possibly due to the lack of CL, whereas the expression of Hsd3bl and Lhcgr was comparable among these groups. The expression of Cyp 17 al was the highest at diestrus and the lowest at estrus, and it was maintained high in PCOS-model mice. The expression of Hsd17bl and Cyp19al in PCOS-model mice was significantly increased compared with that in cycling mice. The ovary of control mice at diestrus and PCOS-model mice showed similar expression of Fshr which was low in the ovary of mice at estrus (Figure 5).

Ovaries from mice at diestrus contained follicles in the variety of follicle stages and CL (Figure 6A), whereas ovaries from PCOS-model mice contained follicles in the variety of follicle stages but no CL (Figure 6E). Ovaries of PCOS-model mice contained fluid-filled cysts and hypertrophied interstitial tissues (Figure 6E).

The histological changes in control and PCOS-model mice after gonadotropin treatments. PMSG injection to both control and PCOS-model mice did not induce any morphological changes in the ovaries of these mice at 3 months of age (Figure 6B and F). However, hCG treatment induced the formation of the cumulus cell-oocyte complex at $8 \mathrm{~h}$ (Figure 6C and $\mathrm{G}$ ) in the ovary of both control and PCOS-model mice followed by ovulation (Figure 6D and $\mathrm{H}$ ). At $24 \mathrm{~h}$ after hCG treatment, all ovaries from both control and PCOS-model mice contained CLs (Figure 6D and H). There was no difference in the total number of antral follicles and the percentage of each follicle type between control and PCOS-model mice (Figure 6I and J). However, the ovary of PCOS-model mice contained cystic follicles without CL before PMSG treatment (Figure 6E and I). PMSG and hCG injections also induced hemorrhagic cysts in the ovary of PCOS-model mice (Figure 6F, G and $\mathrm{H}$ ).

The time-course changes in the gene expression after gonadotropin treatments in the ovary of 3-month-old cycling and PCOS-model mice. To investigate the effects of gonadotropin treatments on the expression of genes involved in

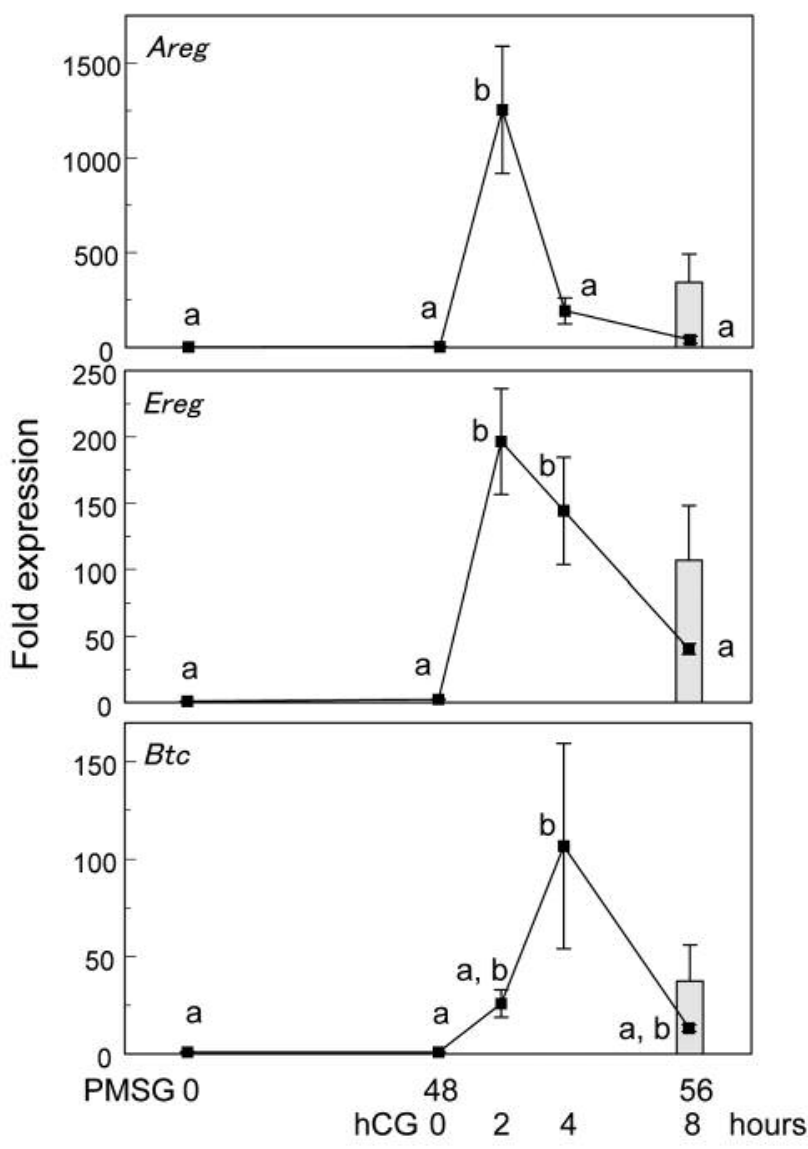

Figure 4. Time course changes in the expression of EGF-like ligand genes, Areg, Ereg and Btc at 0,48 and 56 h after PMSG treatment and 2,4 and $8 \mathrm{~h}$ after hCG treatment. Data were expressed relative to mRNA expression in the ovaries before PMSG $(=1.0)$. Different letters $(a$ and $b$ ) indicate significant changes in the expression of each gene $(p<0.05)$. Closed bar indicates at $56 \mathrm{~h}$ after PMSG injection without $h C G . n=5$ in each group.

steroidogenesis, the expression of Cypllal, Hsd3b1, Cyp17al, Has17b1, Cyp19a1, Lhcgr and Fshr was examined (Figure 7). In control mice, PMSG injection significantly induced the expression of Cypllal and Lhcgr, but had no effect on the expression of Hsd3b1, Cyp17al, Hsd17b1, Cyp19al and Fshr. hCG treatment decreased the expression of genes involved in androgen and estrogen synthesis, including Cyp 17al, Hsd17bl, Cyp19al, Lhcgr and Fshr at $8 \mathrm{~h}$ after the treatment but had no effect on the expression of Cypllal and Hsd3bl which were expressed mainly in the CL. The expression of Lhcgr was reduced by hCG, however, its expression was significantly increased at $48 \mathrm{~h}$ after the treatment.

In PCOS-model mice, PMSG treatment also significantly induced the expression of Cypllal and Lhcgr, however, had no effect on the expression of Hsd3bl, Cypl7al, Hsd17bl 


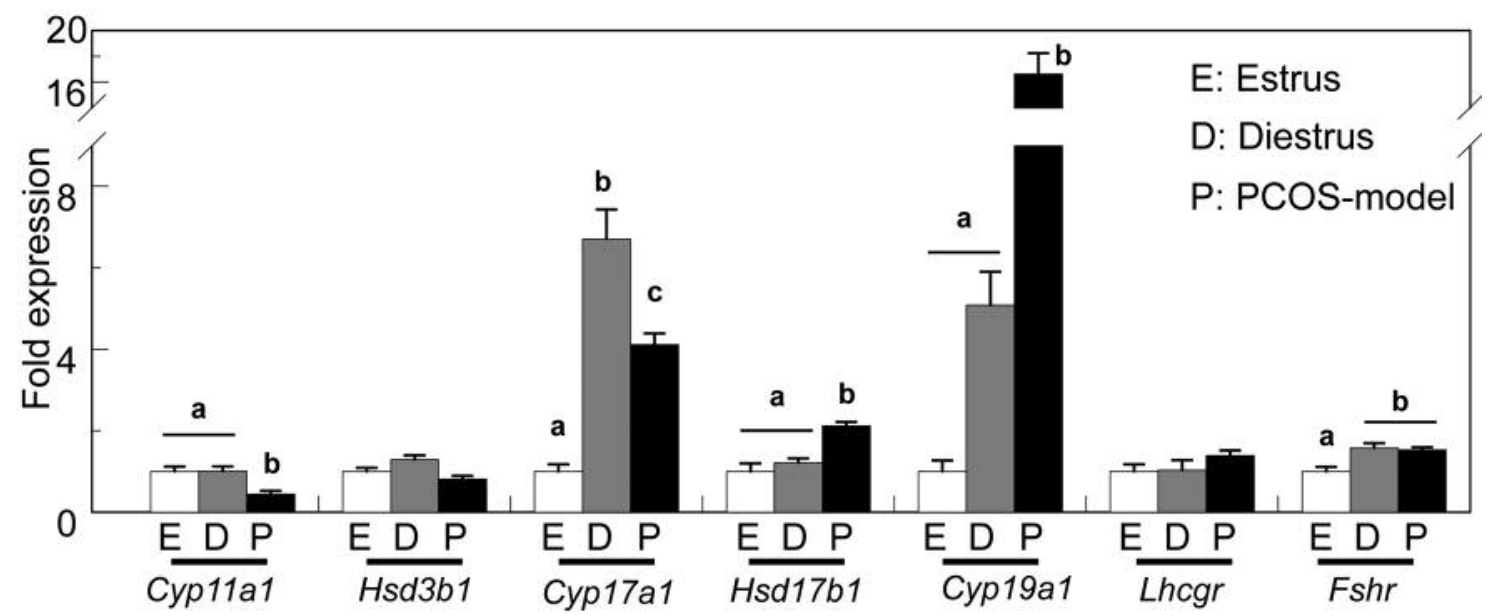

Figure 5. The expression of genes involved in ovarian steroidogenesis of adult control mice at estrus and diestrus and PCOS-model mice. Data were expressed relative to $m R N A$ expression in the ovaries at estrus $(=1.0)$. Different letters $(a, b$ and $c)$ indicate significant changes in the expression of each gene $(p<0.05) . n=5$ in each group.

and Cyp19al (Figure 7). PMSG treatment also resulted in a decrease expression of Fshr in PCOS-model mice. hCG treatment reduced the expression of $H s d 3 b 1$, Cypl7al, Hsd17b1, Cyp19al, Lhcgr and Fshr but had no effect on Cypllal expression, as that in control mice. Interestingly, Cyp17al expression was also reduced in the absence of hCG treatment at $56 \mathrm{~h}$ after PMSG treatment in PCOS-model mice, whereas in control mice the expression of Cyp 17al remained high in the absence of hCG treatment.

The time-course changes of EGF-like ligands and genes involved in luteinization after gonadotropin treatments. The results from experiments using immature mice indicated that the expression of CYP17A1 in theca cells is possibly correlated with ERK1/2 phosphorylation in granulosa cells. EGF-like ligands are well known factors to induce phosphorylation of ERK1/2 through EGF receptor, therefore, the expression and the time-course changes of EGF-like ligands (Areg, Ereg, Btc and Egfr) and genes involved in luteinization including Ptgs2, Sfrp4 and Tnfaip6 were examined.

The expression of Areg, Ereg and Sfrp4 was significantly reduced in the ovary of PCOS-model mice (Figure 8). In both control and PCOS-model mice, hCG treatment transiently induced the expression of Areg at $2 \mathrm{~h}$ while the expression of Ereg, Btc and Tnfaip6 was induced at $2 \mathrm{~h}$ in control mice and at $4 \mathrm{~h}$ in PCOS-model mice (Figure 9). hCG had no effect on the expression of Sfrp 4 in control mice, whereas it increased the expression of Sfrp 4 in PCOSmodel mice at $4 \mathrm{~h}$. hCG induced the expression of Ptgs 2 in control at $2 \mathrm{~h}$ and PCOS-model mice at $4 \mathrm{~h}$ (Figure 9).
The localization of CYP17A1, phospho-ERK1/2 and ERK1/2 in 3-month-old cycling and PCOS-model mice. In control mice at diestrus, CYP17A1, phospho-ERK1/2 and ERK1/2 were observed in theca cells of large antral follicles (Figure 10A, $\mathrm{A}^{*}$ and $\mathrm{A}^{\#}$ ). PMSG induced CYP17A1 expression in theca cells at 48 and $56 \mathrm{~h}$ (Figure $10 \mathrm{~B}$ and $\mathrm{C}$ ), however, phospho-ERK1/2 expression was negative and ERK1/2 expression was positive in those theca cells (Figure 10B*, $\mathrm{C}^{*}, \mathrm{~B}^{\#}$ and $\left.\mathrm{C}^{\#}\right)$. At $8 \mathrm{~h}$ after hCG, 3 out of 5 mice showed follicles with CYP17A1 positive theca cells and no phosphoERK1/2 positive granulosa cells (Figure $10 \mathrm{E}$ and $\mathrm{E}^{*}$ ) and 2 out of 5 mice showed phospho-ERK1/2 positive granulosa cells in follicles without CYP17A1 expression (Figure 10D and $\left.D^{*}\right)$. ERK1/2 expression was positive in those follicles (Figure $10 \mathrm{D}^{\#}$ and $\mathrm{E}^{\#}$ ).

In PCOS-model mice, CYP17A1 was found not only in theca cells but also in the interstitial cells (Figure 10F). PMSG induced CYP17A1 expression in theca cells at 48 and $56 \mathrm{~h}$ in PCOS-model mice (Figure 10G and I) without phospho-ERK1/2 expression in granulosa cells (Figure 10G* and $\mathrm{I}^{*}$ ), however, the ovary of 3 out of 5 mice had follicles containing no CYP17A1 positive theca cells (Figure 10H), and phospho-ERK $1 / 2$ positive granulosa cells at $48 \mathrm{~h}$ after PMSG (Figure 10H*). Especially, the granulosa cells of one PCOS-model mouse at $48 \mathrm{~h}$ after PMSG exhibited intense phospho-ERK1/2 staining (Figure $10 \mathrm{H}^{*}$ ). The ovary of 3 out of 4 PCOS-model mice at $8 \mathrm{~h}$ after hCG contained follicles with no CYP17A1 positive theca cells but phospo-ERK1/2 positive granulosa cells (Figure $10 \mathrm{~J}$ and $\mathrm{J} *$ ). The ovary of one PCOS-model mouse at $8 \mathrm{~h}$ after hCG contained follicles with CYP17A1 positive theca cells but no phospo-ERK1/2 

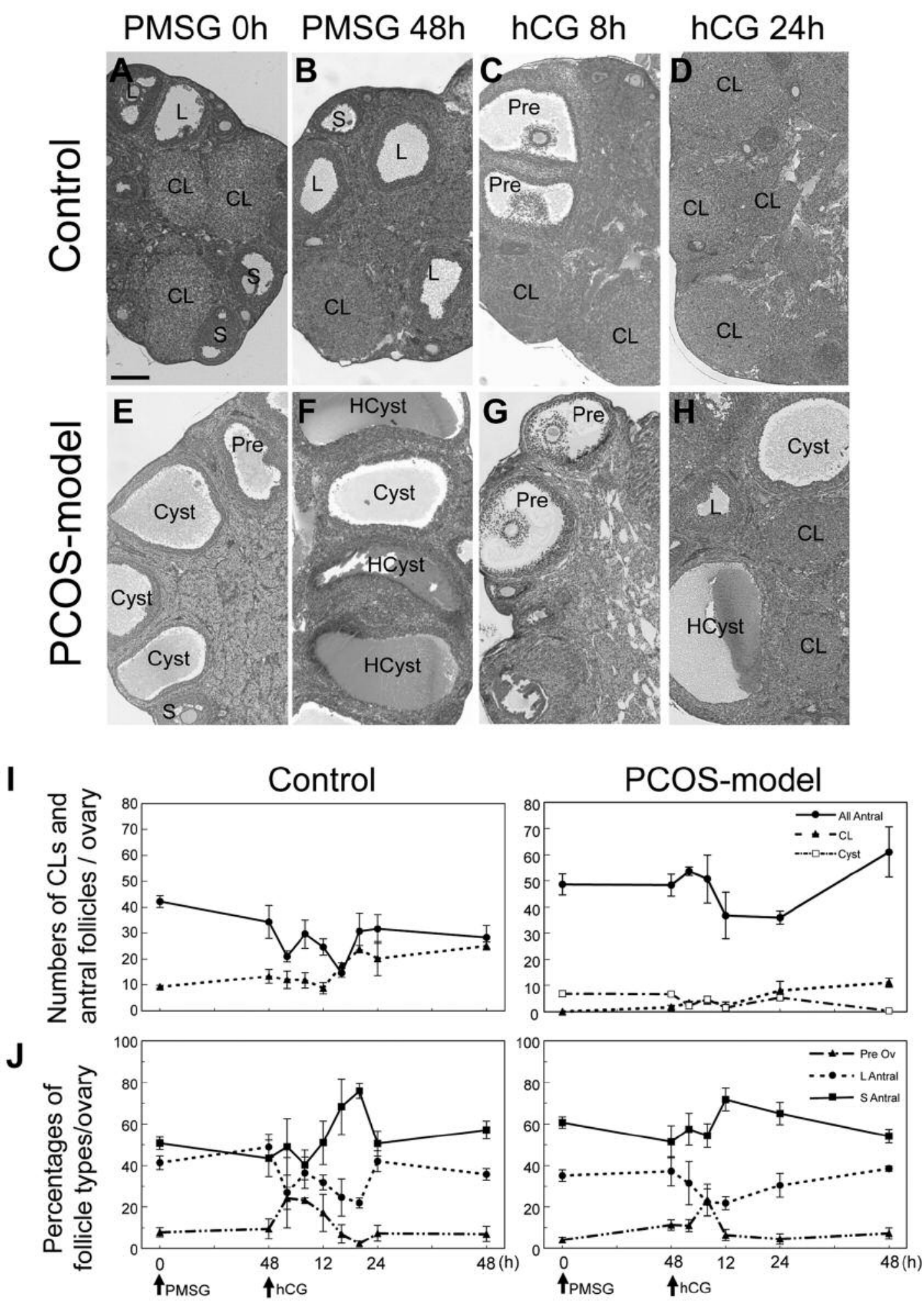

Figure 6. The histology of ovaries from 3-month-old control mice at diestrus (A) and PCOS-model mice (E). Bar=200 $\mu \mathrm{m}$. Effects of PMSG and hCG injections on the ovaries of 3-month-old control and PCOS-model mice. HE staining of 3-month-old control and PCOS model mouse ovaries at 0 (A, $E)$, and $48 \mathrm{~h}$ after PMSG $(B, F), 8(C, G)$ and $24 h(D, H)$ after $h C G$. S, small antral follicle; L: large antral follicle; Pre: preovulatory follicle, CL: corpus luteum, HCyst: hemorrhagic cyst, Cyst, cyst. The total numbers of antral follicles, corpora lutea (CLs) and cysts in ovaries from control and PCOS-model mice were counted at 0 and $48 \mathrm{~h}$ after PMSG injection, and 4, 8, 12, 24 and $48 \mathrm{~h}$ after hCG injection, respectively (I and J). Follicle stage index, preovulatory $(>390 \mu \mathrm{m})$, large antral $(250-390 \mu \mathrm{m})$ and small antral follicles $(140-250 \mu \mathrm{m})$, respectively. $n=5$ in each group. 

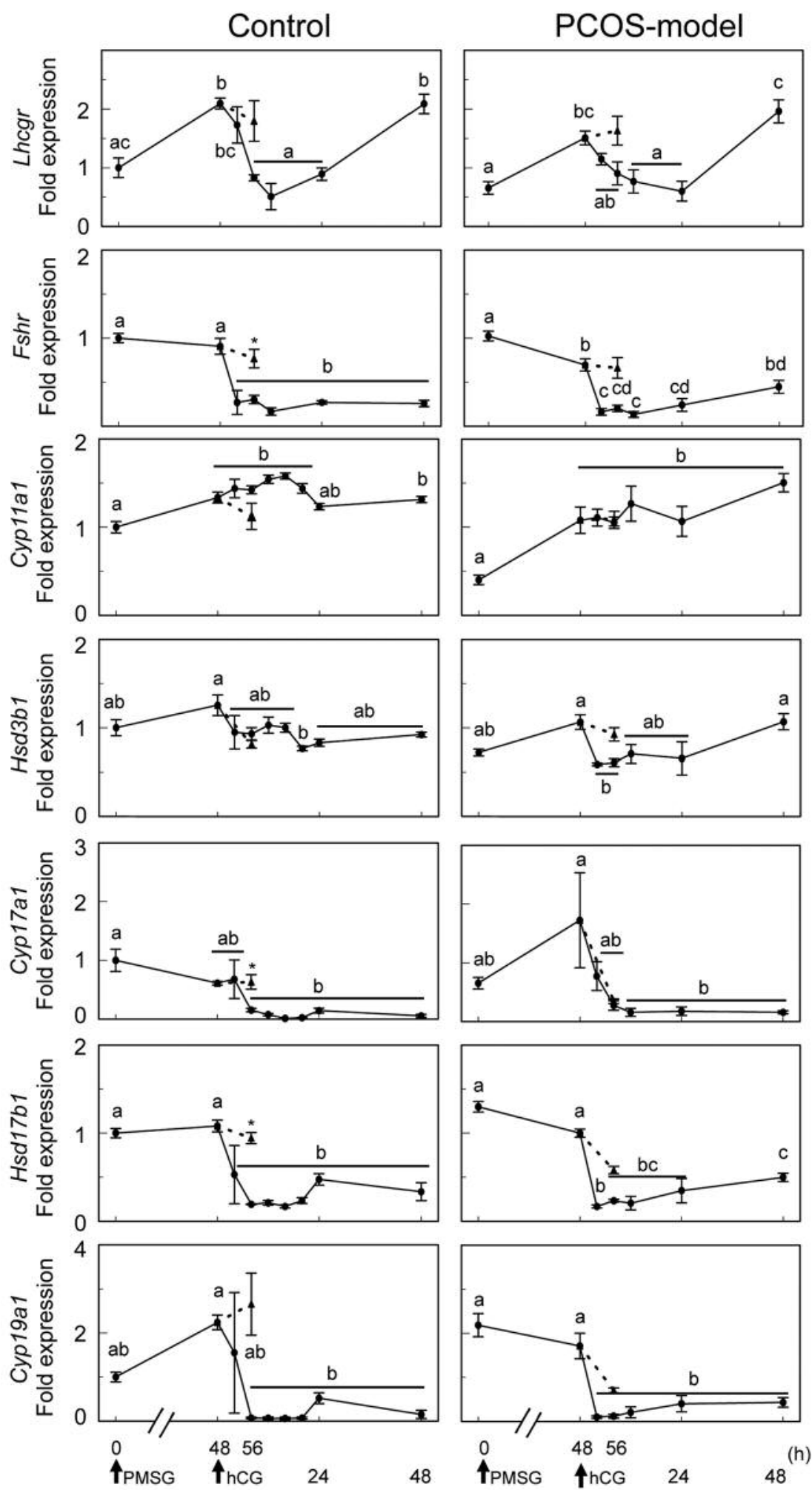

Figure 7. Time-course changes in the expression of genes involved in ovarian steroidogenesis of 3-month-old control and PCOS-model mice at 0 , 48 and $56 \mathrm{~h}$ after PMSG injection and 4, 8, 12,24, 48 h after $h C G$ injection. Data were expressed relative to mRNA expression in the ovaries at diestrus ( $=1.0)$. Different letters ( $a, b, c$ and $d)$ indicate significant changes in the expression of each gene $(p<0.05) .{ }^{*} p<0.05$ significant difference between PMSG-primed mice at $56 \mathrm{~h}$ with or without $h C G$. Straight line and dotted line indicate hCG treatment at $48 \mathrm{~h}$ after PMSG treatment and no hCG treatment, respectively. $n=5$ in each group. 


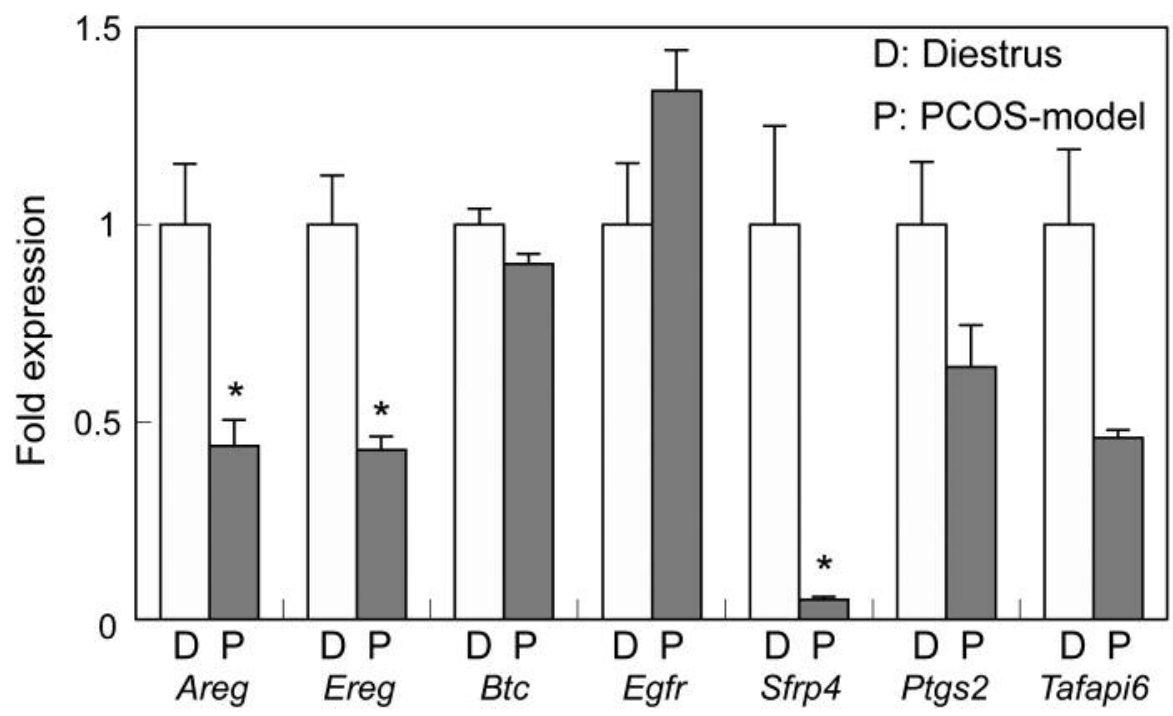

Figure 8. The expression of genes involved in ovulation and luteinization in ovaries from 3-month-old control mice at diestrus and PCOS-model mice. Data were expressed relative to mRNA expression in the ovaries at diestrus $(=1.0) .{ }^{*} p<0.05$ significant difference between control mice at diestrus and PCOS-model mice.

positive granulosa cells (Figure $10 \mathrm{~K}$ and $\mathrm{K}^{*}$ ). ERK1/2 expression was positive in all mice regardless of PMSG or hCG injections (Figure $10 \mathrm{~F}^{\#}, \mathrm{G}^{\#}, \mathrm{H}^{\#}, \mathrm{I}^{\#}, \mathrm{~J}^{\#}$ and $\mathrm{K}^{\#}$ ).

\section{Discussion}

In the ovary, granulosa cells act cooperatively with theca cells in estrogen synthesis regulated by gonadotropins. Our results suggest that granulosa cells can also contribute to the LH regulated expression of Cyp17al in theca cells.

The expression of genes involved in androgen and estrogen production was suppressed by $8 \mathrm{~h}$ after hCG, but this change did not occur without hCG. A decrease of preovulatory follicles occurred at $8 \mathrm{~h}$ after hCG due to the hCG-induced ovulation, while CLs were found at $24 \mathrm{~h}$. These results indicate that hCG caused a decrease of gene expression involved in androgen and estrogen production in theca cells and granulosa cells before CL formation. In PMSG-primed rats, the fall in serum and ovarian E2 levels as well as ovarian androgen levels occurs at 6 and $3 \mathrm{~h}$ after LH injection, respectively (24). Thus, the expression of Lhcgr in granulosa cells is induced by PMSG pretreatment, and subsequently the gene expression involved in androgen and estrogen production can be affected in response to hCG before luteinization.

The present study showed that PMSG stimulation of prepubertal mice induced follicle growth including an increase in the number of large antral and preovulatory follicles with CYP17A1 positive cells, as well as an increase of the expression of Cyp17al and Cyp19al. hCG injection, on the other hand, reduced the expression of Cyp17al and Cyp19al in both prepubertal and cycling 3-month-old mice at $8 \mathrm{~h}$. Immunohistochemistry revealed that when follicles contained phospho-ERK1/2-positive granulosa cells, theca cells were negative for CYP17A1 and vice versa. In Erk1/2 $2^{g c-l-}$ mice, gonadotropin treatments did not induce events associated with ovulation, and E2 levels and the expression of Cyp17al and Cyp19al remained high (6). Since the interaction between theca and granulosa cells is essential not only for the production of steroid hormones but also for differentiation of theca cells (24-27), it is speculated that granulosa cells can contribute to the reduction of Cyp17al expression in theca cells after the hCG injection. EGF-like ligands, such as AREG, EREG and BTC, are considered as the main factors inducing phosphorylation of ERK1/2 in granulosa cells upon hCG treatment. The expression of Cyp17al in theca cells is also increased by inhibin together with LH (4). Thus, the regulation of Cyp 17al expression can be modulated by factors from granulosa cells in addition to $\mathrm{LH}$.

Neonatal TP injections to female mice caused cystic follicles and anovulation, and the expression of Cyp17al maintained high mimicking the typical physiology of women with PCOS. The ovary of PCOS-model mice showed reduced expression of Cypllal compared with that of control mice. This was probably caused by the lack of CL therefore; gonadotropin injections induced the expression of Cypllal as a result of luteinization in PCOS-model mouse ovaries. Interestingly, the expression of Cypl7al remained high at $56 \mathrm{~h}$ after PMSG 

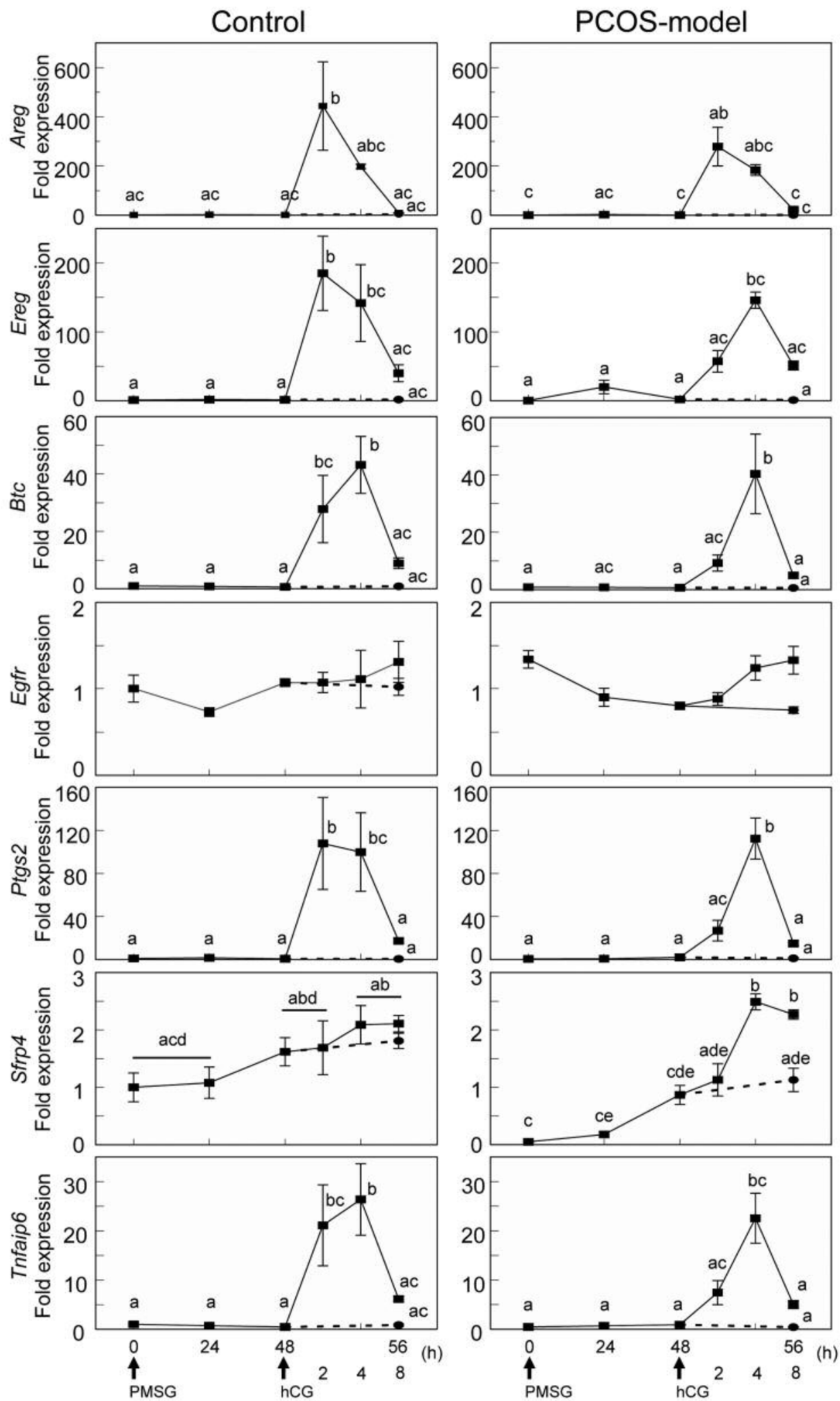

Figure 9. Time course changes in the expression of genes involved in luteinization (Sfrp4, Ptgs2, Tnfaip6) and EGF-like ligands (Areg, Ereg, Btc, Egfr) in ovaries from control and PCOS-model mice at 0, 24, 48, and 56 h after PMSG treatment and 2, 4 and 8 h after hCG treatment. Data were expressed relative to $m R N A$ expression in the ovaries at diestrus $(=1.0)$. Different letters $(a, b, c, d$ and $e)$ indicate significant changes in the expression of each gene $(p<0.05)$. Straight line and dotted line indicate with and without hCG treatment in PMSG-primed mice at 48 , respectively. $n=5$ in each group. 


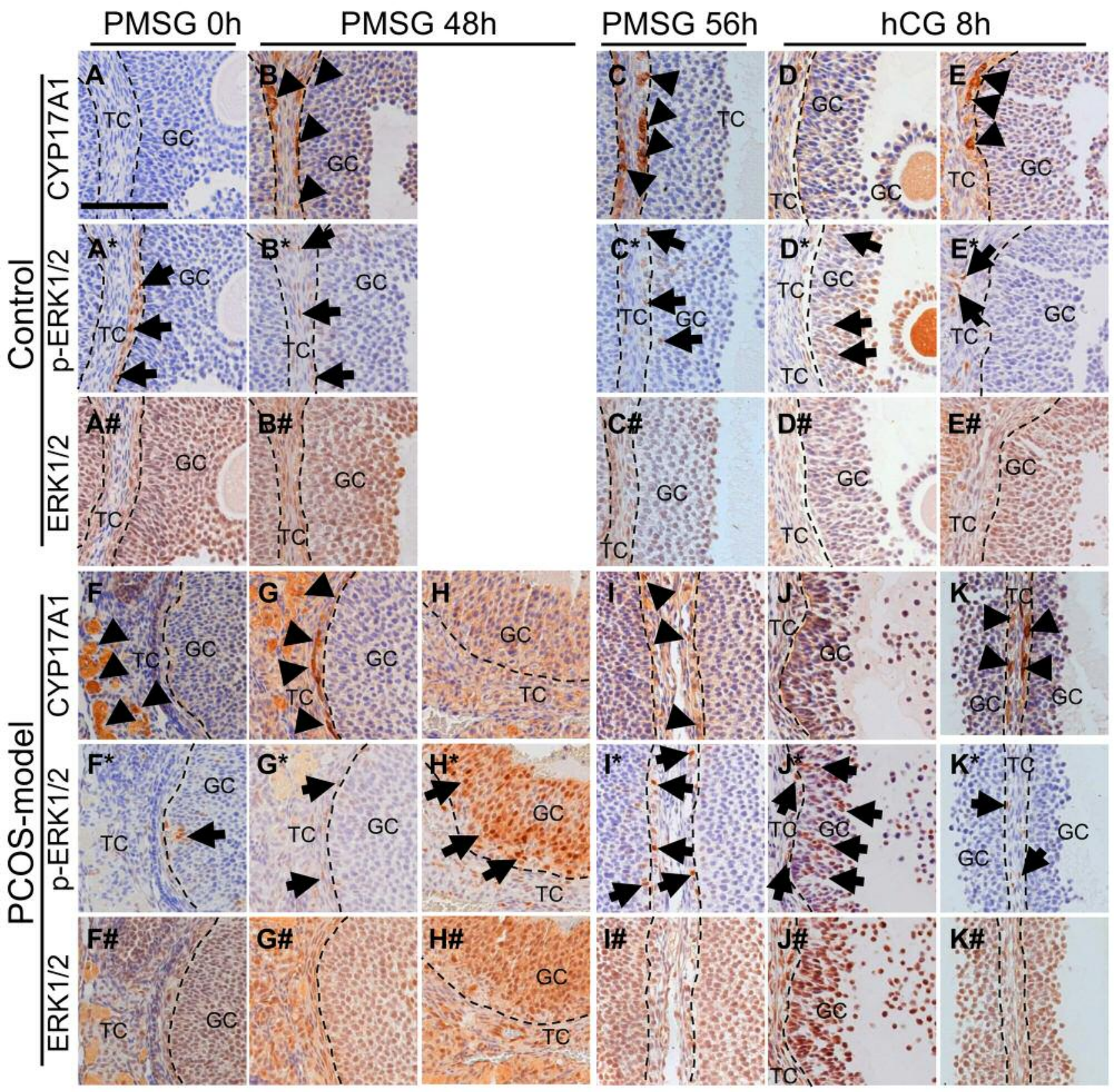

Figure 10. The localization of CYP17A1, phospho-ERK1/2 and ERK1/2 by immunohistochemistry in the ovary of 3-month-old control mice at diestrus $\left(A, A^{*}\right.$ and $\left.A^{\#}\right)$ and PCOS-model mice $\left(F, F^{*}\right.$ and $\left.F^{\#}\right)$. Control mice at $48 \mathrm{~h}$ after PMSG treatment $\left(B, B^{*}\right.$ and $\left.B^{\#}\right), P C O S$-model mice at 48 h after $P M S G$ treatment $\left(G, G^{*}, G^{\#}, H, H^{*}\right.$ and $\left.H \#\right)$, control mice at 56 h after PMSG treatment $\left(C, C^{*}\right.$ and $\left.C^{\#}\right)$ and PCOS-model mice at 56 h after PMSG treatment $\left(I, I^{*}\right.$ and $\left.I^{\#}\right)$ and control mice at $8 \mathrm{~h}$ after $h C G$ treatment $\left(D, D^{*}, D^{\#}, E, E^{*}\right.$ and $\left.E^{\#}\right)$ and PCOS-model mice at $8 h$ after hCG treatment $(J$, $J^{*}, J^{\#}, K, K^{*}$ and $\left.K^{\#}\right)$. Bar=100 $\mu \mathrm{m}$. Arrowheads, CYP17A1 positive cells; arrows, phosho-ERK1/2 positive cells. $n=4-6$ in each group.

injection in both prepubertal and cycling adult mice, whereas it was reduced in PCOS-model mice. In addition, ovaries of 3 mice had follicles containing no CYP17A1 positive theca cells and phospho-ERK1/2 positive granulosa cells at $48 \mathrm{~h}$ after PMSG injection. The expression of Sfrp4, normally upregulated in large antral follicles and CL after hCG injection, was also induced by PMSG in PCOS-model mice. A study using granulosa cell-specific Smad4 conditional knockout mice shows an increase of the expression of luteal markers including Sfrp4 after PMSG injection, suggesting that the lack of SMAD4 signaling in granulosa cells undergoes precocious luteinization in response to gonadotropin stimulation (28), 
whereas the differentiation markers remain intact (e.g. Cdknlb) or are not expressed (e.g. Cdkn2b). Taken together, it is considered that granulosa cells of PCOS-model mice exhibit premature luteinization of granulosa cells as seen in women with PCOS (29). Neonatal mice exposed to TP exhibited characteristics which are observed in women with PCOS, therefore, these mice can be regarded as PCOS-model mice.

Histological analysis revealed that phosphorylation of ERK1/2 in granulosa cells was induced regardless of hCG in PCOS-model mouse ovaries. EGF-like ligands are well-known factors causing phosphorylation of ERK1/2 in granulosa cells after hCG (30). However, PMSG did not induce the expression of Areg, Ereg and Btc both in cycling 3-month-old mice and PCOS-model mice. Vascular endothelial growth factor (VEGF) is one of the factors that activates ERK1/2 in ovaries (31). VEGF and its receptors, VEGFR1 and 2, are expressed in granulosa cells (32-34) and VEGF expression is elevated in luteal phase $(35,36)$. Additionally, the expression of VEGF is regulated by FSH (37) and estrogen (38). Interestingly, VEGF modulates the effects of gonadotropins in granulosa cells via phosphorylation of ERK1/2 (31). PCOS patients have a high risk of ovarian hyperstimulation syndrome (OHSS) which is characterized by increased vascular permeability and simultaneous overexpression of VEGF in ovarian cells normally induced by high dose of hCG (39). These results suggest that the phosphorylation of ERK1/2 in granulosa cells was not caused by EGF-like ligands in PCOS-model mouse ovaries but it may be caused by other factors, such as VEGF.

In conclusion, hCG injection reduced the expression of Cyp17al in ovaries from both prepubertal and cycling adult mice and the reduction of Cyp 17al may be correlated with the phosphorylation of ERK1/2 in granulosa cells after hCG. These facts suggest that granulosa cells may be involved in the regulation of Cyp17al expression in theca cells. Furthermore, PCOS-model mice were established by neonatal TP injections. PMSG reduced the expression of Cypl7al at $56 \mathrm{~h}$ and induced phosphorylation of ERK1/2 in granulosa cells at $48 \mathrm{~h}$ only in PCOS-model mice, suggesting that premature luteinization of granulosa cells can be induced by PMSG. Thus, the interaction between granulosa and theca cells may be impaired in PCOSmodel mice and the study of granulosa cells is important to understand steroidogenesis in the ovary of PCOS women.

\section{Conflicts of Interest}

The Authors declare that there is no conflict of interest.

\section{Acknowledgements}

This work was partially supported by the Ministry of Education, Culture, Sports, Science and Technology of Japan [Grant-in-Aid for Scientific Research (B) to T.I., Grant-in-Aid for Scientific Research (C) to T.S.] and Yokohama City University (Grants for Support of the Promotion of Research, K2109, G2401 and IR2502 to T.S).

\section{References}

1 Le Goascogne $\mathrm{C}$, Sananès $\mathrm{N}$, Gouézou $\mathrm{M}$, Takemori $\mathrm{S}$, Kominami S, Gaulieu EE and Robel P: Immunoreactive cytochrome P-450 $17 \alpha$ in rat and guinea-pig gonads, adrenal glands and brain. J Reprod Fertil 93: 609-622, 1991.

2 Pelletier G, Li S, Luu-The V, Tremblay Y, Bélanger A and Labrie F: Immunoelectron microscopic localization of three key steroidogenic enzymes (cytochrome $\mathrm{P} 450_{\text {scc }}$, 3 $\beta$-hydroxysteroid dehydrogenase and cytochrome $\mathrm{P} 450_{\mathrm{c} 17}$ ) in rat adrenal cortex and gonads. J Endocrinol 171: 373-383, 2001.

3 Magoffin DA: Evidence that luteinizing hormone-stimulated differentiation of purified ovarian theca-interstitial cells is mediated by both type I and type II adenosine 3, ,5, monophosphate-dependent protein kinases. Endocrinology 125 : 1464-1473, 1987.

4 Young JM and McNeilly AS: Inhibin removes the inhibitory effects of activing on steroid enzyme expression and androgen production by normal ovarian thecal cells. J Mol Endocrinol 48: 49-60, 2012.

5 Chen M, Li T, Ding C, Xu Y, Guo L and Zhou C: Growth differential factor-9 inhibits testosterone production in mouse theca interstitial cells. Fertil Steril 100: 1444-1450, 2013.

6 Fan H, Liu Z, Shimada M, Sterneck E, Johnson PF, Hedrick SM and Richards JS: MAPK3/1 (ERK1/2) in ovarian granulosa cells are essential for female fertility. Science 324: 938-941, 2009.

7 Fauser BC, Tarlatzis BC, Rebar RW, Legro RS, Balen AH, Lobo R, Carmina E, Chang J, Yuldiz BO, Laven JS, Boivin J, Petraglia F, Wijeyeratne CN, Norman RJ, Dunaif A, Franks S, Wild RA, Dumesic D and Barnhart K: Consensus on women's health aspects of polycystic ovary syndrome (PCOS): the Amsterdam ESHRE/ASRM-Sponsored 3rd PCOS Consensus Workshop Group. Fertil Steril 97: 28-38, 2012.

8 Hart R and Doherty DA: The potential implications of a PCOS diagnosis on a woman's long-term health using data linkage. J Clin Endocrinol Metab 100: 911-919, 2015.

9 Chang RJ, Laufer LR, Meldrum DR, DeFazio J, Lu JK, Wale WW, Rivier E and Judd HL: Steroid secretion in polycystic ovarian disease after ovarian suppression by a long-acting gonadotropin-releasing hormone agonist. J Clin Endocrinol Metab 56: 897-903, 1983.

10 Nelson VL, Legro RS, Strauss JF III and McAllister JM: Augmented androgen production is a stable steroidogenic phenotype of propagated theca cells from polycystic ovaries. Mol Endocrinol 13: 946-957, 1999.

11 Nelson VL, Qin K, Rosenfield RL, Wood JR, Penning TM, Legro RS, Strauss JF III and McAllister JM: The biochemical basis for increased testosterone production in theca cells propagated from patients with polycystic ovary syndrome. J Clin Endocrinol Metab 86: 5925-5933, 2001.

12 Kenigsberg S, Bentov Y, Chalifa-Caspi V, Potashnik G, Ofir R and Birk OS: Gene expression microarray profiles of cumulus cells in lean and overweight-obese polycystic ovary syndrome patients. Mol Hum Reprod 15: 89-103, 2009.

13 Lan C, Chen M, Yai K, Yu D, Yang YC, Jan P, Yang Y, Chen H and Ho H: Functional microarray analysis of differentially expressed genes in granulosa cells from women with polycystic ovary syndrome related to MAPK/ERK signaling. Sci Rep 5: 14994, 2015. 
14 Ambekar AS, Kelkar DS, Pinto SM, Sharma R, Hinduja I, Zaveri K, Pandey A, Prasad TSK, Gowda H and Mukherjee S: Proteomics of follicular fluid from women with polycystic ovary syndrome suggests molecular defects in follicular development. J Clin Endocrinol Metab 100: 744-753, 2015.

15 Walters KA, Allan CM and Handelsman DJ: Rodent models for human polycystic ovary syndrome. Biol Reprod 86: 149, 1-12, 2012.

16 Huffman L and Hendricks SE: Prenatally injected testosterone propionate and sexual behavior of female rats. Physiol Behav 26: 773-778, 1981.

17 Swanson HE and Werfftenbosch JJ: The "early-androgen" syndrome; differences in response to pre-natal and post-natal administration of various doses of testosterone propionate in female and male rats. Acta Endocrinol 47: 37-50, 1964.

18 Pinilla L, Trimino E, Garnelo P, Bellido C, Aguilar R, Gaytan F and Aguilar E: Changes in pituitary secretion during the early postnatal period and anovulatory syndrome induced by neonatal oestrogen or androgen in rats. J Reprod Fertil 97: 13-20, 1993.

19 McDonald PG and Doughty C: Comparison of the effect of neonatal administration of testosterone and dihydrotestosterone in the female rat. J Reprod Fertil 30: 55-62, 1972.

20 Ota H, Fukushima $M$ and Maki M: Endocrinological and histological aspects of the process of polycystic ovary formation in the rat treated with testosterone propionate. Tohoku J Exp Med 140: 121-131, 1983.

21 Edwards DA: Neonatal administration of androstendione, testosterone or testosterone propionate: effects on ovulation, sexual receptivity and aggressive behavior in female mice. Physiol Behav 6: 223-228, 1971.

22 Kamijo T, Mizunuma H, Yamada K, Ibuki Y: In vitro fertilization of androgen sterilized mice. Life Sciences 55: 527-531, 1994.

23 Wu XY, Li ZL, Wu CY, Liu YM, Lin H, Wang Sha and Xiao WF: Endocrine traits of polycystic ovary syndrome in prenatally androgenized female Sprague-Dawley rats. Endocrine Journal 57: 201-209, 2010.

24 Katz Y and Armstrong DT: Inhibition of ovarian estradiol-17 $\beta$ secretion by luteinizing hormone in prepubertal, pregnant mare serum-treated rats. Endocrinology 99: 1442-1447, 1976.

25 Honda A, Hirose M, Hara K, Matoba S, Inoue K, Miki H, Hiura H, Kanatsu-Shinohara M, Kanai Y, Kono T, Shinohara T and Ogura A: Isolation, characterization, and in vitro and in vivo differentiation of putative thecal stem cells. PNAS 104: 1238912394, 2007.

26 Liu C, Peng J, Matzuk MM and Yao HH: Lineage specification of ovarian theca cells requires multicellular interactions via oocyte and granulosa cells. Nat Commun 6: 6934, 2015.

27 Kawai T, Mihara T, Kawashima I, Fujita T, Ikeda C, Negishi H, Richards JS and Shimada M: Endogenous acetaldehyde toxicity during antral follicular development in the mouse ovary. Reprod Toxicol 33: 322-330, 2012.
28 Pangas SA, Li X, Robertson EJ and Matzuk MM: Premature luteinization and cumulus cell defects in ovarian-specific Smad4 knockout mice. Mol Endocrinol 20: 1406-1422, 2006.

29 Willis DS, Watson H, Mason HD, Galea R, Brincat M and Franks S: Premature response to luteinizing hormone of granulosa cells from anovulatory women with polycystic ovary syndrome: Relevance to mechanism of anovulation. J Clin Endocrinol Metab 83: 3984-3991, 1998.

30 Yamashita Y and Shimada M: The release of EGF domain from EGF-like factors by a specific cleavage enzyme activates the EGFR-MAPK3/1 pathway in both granulosa cells and cumulus cells during the ovulation process. J Reprod Dev 58: 510-514, 2012.

31 Doyle LK, Walker CA and Donadeu FX: VEGF modulates the effects of gonadotropins in granulosa cells. Domest Anim Endocrinol 38: 127-137, 2010.

32 Fraser HM and Wulff C: Angiogenesis in the primate ovary. Reprod Fertil Dev 13: 557-566, 2002.

33 Grasselli F, Basini G, Bussolati S and Tamanini C: Effects of VEGF and bFGF on proliferation and production of steroids and nitric oxide in porcine granulosa cells. Reprod Domest Anim 37: 362-368, 2002.

34 Greenaway J, Connor K, Pedersen HG, Coomber BL, Lamarre $\mathrm{J}$ and Petrik J: Vascular endothelial growth factor and its receptor, Flk-1/KDR, are cytoprotective in the extravascular compartment of the ovarian follicle. Endocrinology 145: 28962905,2004

35 Ferrara N, Chen H, Davis-Smyth T, Gerber HP, Nguyen TN, Peers D, Chisholm V, Hillan LJ and Schwall RH: Vascular endothelial growth factor is essential for corpus luteum angiogenesis. Nat Med 4: 336-340, 1998.

36 Al-zi'abi MO, Watson ED and Fraser HM: Angiogenesis and vascular endothelial growth factor expression in the equine corpus luteum. Reproduction 125: 259-270, 2003.

37 Zhang Z, Wang Q, Ma J, Yi X, Zhu Y, Xi X, Feng Y and Jin Z: Reactive oxygen species regulate FSH-induced expression of vascular endothelial growth factor via Nrf2 and HIF1 $\alpha$ signaling in human epithelial ovarian cancer. Oncol Rep 29: 1429-1434, 2013.

38 Danforth DR, Arbogast LK, Ghosh S, Dickerman A, Rofagha R and Friedman CI: Vascular endothelial growth factor stimulates preantral follicle growth in the rat ovary. Biol Reprod 69: 17361741, 2003.

39 Peitsidis P and Agrawal R: Role of vascular endothelial growth factor in woman with PCO and PCOS: a systematic review. Reprod Biomed Online 20: 444-452, 2010.

Received August 7, 2018

Revised September 19, 2018

Accepted September 21, 2018 